\title{
KARAKTERISASI EDIBLE COATING DARI MODIFIKASI PATI SAGU DENGAN METODA CROSS LINK
}

\section{CHARACTERIZATION OF EDIBLE COATING FROM MODIFIED SAGO STARCH WITH CROSS LINK METHOD}

\author{
Dewi Sondari*) dan Imad Iltizam \\ Research Center for Chemistry-LIPI, Kawasan Puspiptek Serpong, South Tangerang, Banten Province 15314 \\ Email :sondaridewi@gmail.com
}

Makalah: Diterima 10 September 2018; Diperbaiki 2 Desember 2018; Disetujui 12 Desember 2018

\begin{abstract}
This study aims to make edible coating of native sago and modified sago by crosslink method and analyze physicochemical properties. Analysis of swelling power, amylose content, fat content, protein content, degree of substitution, and gelatinization temperature have been performed against native starch and modified starch. Furthermore, the identification of organic compounds on natural starch and modified starch was carried out by Fourier Transform Infrared (FTIR) and structural morphology of starch using Scanning Electron Microscopy (SEM). Analysis of edible coatings includes mechanical properties, moisture content, and film morphology using SEM. The results showed that the starch modified by crosslink method has physicochemical properties better than the native starch.
\end{abstract}

Keywords :cross link, sago, physicochemical property, modified starch, edible coating

\begin{abstract}
ABSTRAK
Penelitian ini bertujuan untuk membuat edible coating dari sagu alami dan sagu yang dimodifikasi secara cross link serta menganalisis sifat fisika kimianya. Analisis terhadap swelling power, kadar amilosa, kadar lemak, kadar protein, derajat subsitusi, dan temperatur gelatinisasi telah dilakukan. terhadap pati alami dan pati yang telah di modifikasi. Selanjutnya identifikasi senyawa organik terhadap pati alami dan pati yang dimodifikasi dilakukan menggunakan Fourier Transform Infrared (FTIR) dan morfologi struktur dari pati menggunakan Scanning Electron Microscopy (SEM). Analisis terhadap edible coating meliputi sifat mekanik, kadar air, dan morfologi film menggunakan SEM. Hasil penelitian menunjukkan bahwa modifikasi secara cross link menghasilkan pati yang mempunyai sifat fisika kimia lebih baik dari pati alaminya.
\end{abstract}

Kata kunci :cross link, sagu, SEM, FTIR, modifikasi pati, edible coating

\section{PENDAHULUAN}

Sagu merupakan salah satu tanaman yang bernilai ekonomis tinggi dan mempunyai potensi untuk dikembangkan sebagai bahan pangan.Pada industri pangan tepung sagu mulai digunakan sebagai bahan untuk pembuatan roti, biskuit mie (noodle), sohun, kerupuk, hunkue, bihun dan lainlain, sebagai pengganti penggunaan tepung terigu, tapioka, atau tepung beras. Penggunaan pati dalam industri memiliki keterbatasan diantaranya memerlukan waktu pemasakan yang lama serta pasta yang terbentuk keras dan tidak bening. Retrogradasi dan sineresis yang tinggi, ketahanan panas dan kelarutan yang rendah, dan tidak tahan terhadap kondisi asam merupakan beberapa kendala dalam penggunaan pati. Untuk meningkatkan sifat-sifat fisik-kimia dari pati maka dilakukan modifikasi pati (Mirmoghtadaie et al., 2009; Cock, 1982; Miyazaki et al., 2006).

Pati termodifikasi adalah pati diberi menghasilkan sifat yang lebih baik dari sifat sebelumnya, dengan cara mengubah gugus hidroksil melalui suatu reaksi kimia seperti esterifikasi, sterifikasi atau oksidasi (Singh et al., 2007; Huang et al., 2007). Sifat-sifat yang diinginkan dari pati yang dimodifikasi antara lain memiliki viskositas yang stabil pada suhu tinggi dan rendah, daya tahan terhadap "sharing" mekanis yang baik serta mempunyai sifat sebagai pengental yang tahan terhadap kondisi asam dan suhu sterilisasi (Diab et al., 2001; Abdorreza et al., 2012). Oksidasi pati merupakan salah satu bentuk modifikasi kimia, dan menjadi metode modifikasi yang penting dan banyak digunakan. Hal ini disebabkan pati yang dihasilkan memiliki viskositas yang rendah, stabilitas pasta yang tinggi, sifat ikatan dan pembentukan film yang baik serta kejernihan yang lebih tinggi (Rivera et al., 2005). Pati teroksidasi juga dapat diaplikasikan secara lebih luas dalam berbagai industri seperti kertas, tekstil, laundry, serta sebagai bahan pelapis permukaan (Kuakpetoon dan wang, 2006).

Selain sebagai bahan baku industri, pati telah banyak juga digunakan sebagai bahan baku alternatif untuk pembuatan pelapis layak makan (edible coating). karena bersifat biodegradable, bahan baku mudah diperoleh, harga murah dan 
ramah lingkungan serta meningkatnya permintaan konsumen untuk makanan yang aman pangan (food grade), selain itu, pati dapat membentuk film (film forming) yang kuat dan transparan (Teressa dan Silva, 2011; Chopin et al.,2014).

Penelitian modifikasi pati sagu secara cross link bertujuan untuk meningkatkan sifat fungsional dan sifat mekanik dari pati sagu, sehingga pati yang dihasilkan mempunyai sifat kelarutan yang tinggi, swelling power yang rendah, granula pati yang lebih mudah pecah, serta waktu, suhu gelatinisasi yang lebih tinggi, elongasi dan tensile strength yang kuat.

Ruang lingkup yang dilakukan dalam penelitian ini adalah karakterisasi pati sagu alami, modifikasi pati sagu secara cross link dengan variasi konsentrasi natrium asetat sebagai agen cross link, karakterisasi pati yang di modifikasi, pembuatan edible coating dari pati sagu alami dan pati yang di modifikasi dan karakterisasinya.

Agen cross link yang biasa digunakan dalam modifikasi pati biasanya adalah $\mathrm{POCl} 3$ (Phosphorus Oxychloride), STMP (Sodium trimetaphosphate) dan EPI (Epichlorohyde). Dalam penelitian ini akan digunakan agen cross link natrium asetat selain mudah didapat juga harga lebih murah dibandingkan agen cross link lainnya. Hasil modifikasi pati dengan natrium asetat diharapkan diperolehnya pati modifikasi natrium.

\section{BAHAN DAN METODE}

\section{Bahan dan Alat}

Sagu, natrium hidroksida, natrium asetat, silikon oksida, amilosa, kalium sulfat, indikator phenolphthalein, n-heksan (Merck, Darmstadt, Germany). Gliserol, cawan porselen, cawan petridish, furnace, oven, desikator, alat sokletasi, alat insrtumen spektrofotometer UV-Vis, SEM HITACHI SU3500, contact angle meter model CAM-PLUS MICRO (Tantec Inc., USA), FTIR Prestige 21 Shimazu.

\section{Metodologi}

Modifikasi Sagu Metoda Cross Link

Pati sagu ditambahkan aquades dan silikon oksida diaduk selama 5 menit, kemudian ditambahkan larutan natrium hidroksida dan diaduk selama 20 menit. Setelah itu ditambahkan agen cross link natrium asetat dengan variasi 10\%, 15\%,
$20 \%$ dan $25 \%$ dari berat pati dan diaduk selama 15 menit, kemudian dipanaskan di water bath dengan suhu $40^{\circ} \mathrm{C}$ selama 1 jam, kemudian disaring dan keringkan dalam oven suhu $50^{\circ} \mathrm{C}$ selama 3 jam (Akpa, 2012).

\section{Pembuatan Edible film}

Sampel sagu murni dan sagu ang di modifikasi dengan metoda cross link. Agen cross link yang digunakan natrium asetat dengan variasi 1,0-2,5\%. Pati sagu ditambah aquades kemudian larutan dipanaskan dalam water bath, setelah terbentuk gel ditambahkan gliserol sampai homogen, setelah dingin ditimbang dan dituang kedalam cawan petri sebanyak 10 gram dan dikeringkan pada suhu $50^{\circ} \mathrm{C}$ selama 24 jam (Moreno, 2017).

\section{Karakterisasi}

Karakterisasi terhadap sagu murni dan sagu yang sudah di modifikasi secara oksidasi meliputi kadar air, kadar lemak dan kadar abu dilakukan berdasarkan metode Nielsen, S (2017), kadar amilosa berdasarkan metode Northrop (1926), kelarutan dan swelling power dilakukan berdasarkan metode Senanayake et al. (2013), dan suhu gelatinisasi dilakukan berdasarkan metode Akpa et al. (2012). Analisis gugus fungsional pati sagu murni dan sagu yang modifikasi menggunakan FTIR pada bilangan gelombang 4000-400 $\mathrm{cm}^{-1}$, dilakukan di laboratorium Pusat penelitian Kimia LIPI. Analisis morfologi pati sagu murni dan modifikasi menggunakan mikroskop elektron scanning (SEM) HITACHI SU3500 dilakukan di Pusat Penelitian Fisika LIPI. Analisis kadar air pada edible film dilakukan dengan metoda (Moreno et al., 2017), sudut kontak dengan metoda metode Ballesterosa et al. (2018) dilakukan di SBRC IPB, SEM, tensile strength dan elongasi dilakukan terhadap edible coating.

\section{HASIL DAN PEMBAHASAN}

\section{Karakterisasi Pati Sagu Alami dan Pati Sagu Modifikasi}

Pati sagu alami dan pati sagu yang dimodifikasi secara cross link telah diidentifikasi sifat fisika kimianya seperti yang terlihat pada Tabel 1.

Tabel 1. Sifat fisika kimia pati sagu alami dan pati sagu modifikasi

\begin{tabular}{lccccc}
\hline \multicolumn{1}{c}{ Analisa } & \multirow{2}{*}{ Sagu murni } & \multicolumn{4}{c}{ Modifikasi cross link sagu } \\
\cline { 3 - 6 } & & $\mathbf{1 0 \%}$ & $\mathbf{1 5 \%}$ & $\mathbf{2 0 \%}$ & $\mathbf{2 5 \%}$ \\
\hline Kadar air (\%) & 11,46 & 14,82 & 14,13 & 14,11 & 13,39 \\
Kadar abu (\%) & 1,04 & 0,28 & 0,51 & 0,94 & 0,86 \\
Kadar amilosa (\%) & 25,85 & 21,50 & 22,16 & 22,80 & 22,64 \\
Suhu gelatinisasi $\left({ }^{\circ} \mathrm{C}\right)$ & 68 & 78 & 78 & 78 & 79 \\
Kelarutan $(\%)$ & 0 & 21,92 & 41,14 & 42,05 & 50,1 \\
Swelling power $(\%)$ & 15,13 & 5,56 & 6,59 & 6,34 & 6,26 \\
\hline
\end{tabular}


Hasil pada Tabel 1. menunjukkan bahwa modifikasi dengan cross-linking meningkatkan kadar air dari pati. Pati yang dimodifikasi dengan natrium asetat menggunakan katalis natrium hidroksida memiliki kandungan air tertinggi 14,82\%. Kadar air dalam sampel tidak melebihi batas maksimum yang diperbolehkan, dimana batas maksimum yang diijinkan untuk kelembaban dalam tepung pati adalah 14\%-15\% (Austin, 1984; Winarno, 1989). Kadar air yang tinggi mendorong pertumbuhan organisme yang menyebabkan bau dan rasa tidak enak pada pati. Menurut Winarno (1989) kadar bahan pangan dengan kadar air kurang dari $15 \%$ tergolong bahan pangan kering. Kadar air pada penelitian ini lebih tinggi daripada kadar air yang dilakukan oleh peneliti sebelumnya (Mahmut dan Sosulski, 2004; Huang et al.,(2007); Akpa et al., 2012). Menurut Yuliasih (2008) menyatakan bahwa komposisi kimia, sifat fisik maupun sifat fungsional pati, di antaranya pati sagu dipengaruhi oleh daerah atau tempat dimana sumber pati tersebut tumbuh. Selain kondisi diatas, diduga adanya perbedaan lama waktu pengeringan dan kondisi penyimpanan sebelum analisa mempengaruhi kadar air suatu bahan pangan. Fellow (2000) menerangkan bahwa faktor-faktor yang mempengaruhi proses pengeringan suatu bahan pangan adalah kadar air awal bahan, kelembaban lingkungan, dan media perantara pemindahan panas.

Kandungan abu dalam sampel merupakan senyawa anorganik yang tidak mudah menguap pada pati sagu setelah mengalami dekomposisi pada suhu tinggi dan berhubungan dengan unsur mineral yang terdapat dalam bahan. Modifikasi dengan cross-link meningkatkan kadar abu dari pati (Alejandro et al.,2008). Kadar abu dari pati sagu yang dimodifikasi dengan cross link lebih besar dari kadar abu pati sagu alami, terjadinya peningkatan kadar abu disebabkan oleh kehadiran natrium yang berasal dari agen cross link natrium asetat dalam ke dalam granula pati dan berikatan dengan rantai polimer pati. Seperti yang dilaporkan Herlina (2010) menyatakan bahwa meningkatnya kadar abu pada pati yang dimodifikasi disebabkan karena natrium yang digunakan untuk bahan pemodifikasi.

Kadar amilosa dari pati sagu yang telah dimodifikasi mengalami penurunan, hal ini disebabkan karena gugus $\mathrm{OH}$ pada amilosa diikat oleh senyawa natrium asetat sebagai agen cross link (Akpa et al., 2012), sehingga sifat amilosa mengalami perubahan. Amilosa merupakan molekul yang berbentuk rantai lurus dan mempunyai gugus fungsional dengan posisi yang lebih terbuka, terutama gugus hidroksil $(-\mathrm{OH})$ pada atom $\mathrm{C}$ nomor 2 sangat bebas dan sangat reaktif sehingga mudah bereaksi dengan senyawa lain (Van de Burgt et al., 2000). Molekul amilosa merupakan bagian molekul yang amorf, sehingga gugus $\mathrm{OH}$ pada bagian amorf dua kali lebih mudah disubstitusi dengan gugus lain per unit anhidroglukosa dibandingkan dengan amilopektin. Hasil penelitian ini sejalan dengan yang dilakukan oleh Lopez et al.,(2010) bahwa kadar amilosa pada pati yang dimodifikasi dengan menggunakan metodacross link lebih kecil dibandingkan dengan pati alaminya.

Suhu gelatinisasi pati merupakan suhu di mana pati membentuk gel transparan secara keseluruhan. Pada proses gelatinisasi terjadi pecahnya ikatan antar molekul-molekul pati dengan adanya air dan panas. Gelatinisasi pati membutuhkan banyak air dan penetrasi air ini meningkatkan keacakan dalam struktur pati. Semakin kuat ikatan antara molekul pati, semakin tinggi jumlah panas yang diperlukan untuk memecah ikatan antarmolekul dan semakin tinggi suhu gelatinisasi (Sodhi dan Singh, 2005). Modifikasi pati sagu dengan metoda cross link menambah kuatnya ikatan antar molekul sehingga granula pati semakin kuat dan stabil, hal ini menyebabkan meningkatnya temperature gelatinisasi pati, penelitian ini sejalan dengan yang dilakukan oleh peneliti sebelumnya (Acquarone dan Rao, 2003). Kecenderungan ini ditunjukkan pada Tabel 1 karena semua pati yang dimodifikasi memiliki suhu gel lebih tinggi daripada pati asli. Choi dan Kerr (2004) melaporkan hasil penelitian pati gandum dengan metoda cross-link meningkatkan suhu gelatinisasi. Peningkatan suhu gelatinisasi ini dipengaruhi oleh sumber botani pati, konsentrasi, jenis reagen cross link dan kondisi reaksi (Chel-Guerrero dan Betancur, 1998).

Menurut Hoover dan Sosulski, (1986), kelarutan dan swelling power pati dipengaruhi oleh jenis agen cross link. Dengan adanya ikatan silang antar molekul pati maka akan memperkuat ikatanhidrogen pada rantai pati menyebabkan berkurangnya pergerakan molekul patisehingga air sulit menembus kedalam granula pati (Wang dan Wang, 2003). Hasil penelitian menunjukkan bahwa terjadinya peningkatan kelarutan dan penurunan swelling power pada pati sagu yang di modifukasi dibandingkan dengan pati alami seperti yang ditunjukkan pada Tabel 1. Kemampuan mengembang (swelling power) berhubungan dengan komposisi amilopektin dan amilosa dalam suatu pati seperti yang disampaikan oleh Sasaki dan Masuki (1998) dan Srichowang et al.(2005). Semakin meningkat kadar amilosa, semakin tinggi kemampuan mengembang, sebagaimana hasil penelitian Davies et al., (2008). Kadar amilosa pati sagu setelah di modifikasi secara cross link mengalami penurunan dibandingkan dengan pati sagu alami sepertiyang ditunjukkan dalam Tabel 1, hal ini menunjukkan adanya korelasi dengan terjadinya penurunan swelling power.

Hasil dari modifikasi dengan cross link pada Tabel 1 menunjukkan peningkatan kelarutan semua pati yang dimodifikasi dengan pati modifikasi natrium asetat. Kelarutan tertinggi $50,1 \%$ pada konsentrasi agen cross link 25\%, menunjukkan peningkatan keacakan dalam struktur pati dan 
pecahnya butiran pati. Semakin tinggi konsentrasi agen cross link natrium asetat maka kelarutannya semakin meningkat, hal ini disebabkan oleh banyaknya gugus $\mathrm{OH}$ yang disubstitusi, karena melemahnya ikatan hidrogen. Melemahnya ikatan hidrogen dalam pati menyebabkan air mudah masuk kedalam granula pati. Dengan semakin mudahnya air masuk maka kecenderungan membentuk ikatan hidrogen antara pati dengan molekul air menjadi lebih besar. Ikatan hidrogen ini akan menahan air untuk keluar dari granula pati sehingga pati tersebut mudah larut, hal ini sejalan dengan penelitian yang dilakukan oleh Tedja et al. (2008). Pati sagu alami dan sagu yang telah di modifikasi melalui cross link diidentifikasi senyawa gugus fungsinya menggunakan FTIR.

Dari spektrum pada Gambar 1. terlihat adanyaserapan pada panjang gelombang 3561,71 $\mathrm{cm}^{-1}$ yang menunjukkan gugus -OH dari amilosa. Nampak gugus -C-O-C- pada puncak pada 1150,56 $\mathrm{cm}^{-1}$, dan gugus karbonil pada puncak $1720,68 \mathrm{~cm}^{-1}$ yang menunjukkan terjadinya crosslink antara pati sagu dengan agen cross link. Pembuatan sagu yang modifikasi dipengaruhi oleh banyaknya agen pengikat silang yang digunakan. Hal ini disebabkan karena semakin banyak agen cross link yang digunakan maka semakin banyak gugus $\mathrm{OH}$ yang di substitusi, karena melemahnya ikatan hydrogen.

Analisis SEM dilakukan untuk melihat morfologi dari pati alami dan pati sagu hasil modifikasi seperti yang terlihat pada Gambar 2. Bentuk pati sagu alami dan pati sagu yang di modifikasi berbentuk granula-granula oval dan tidak mengalami perubahan yang berbeda. Hasil penelitian ini sejalan dengan penelitiWurzburg (1989) yang menyatakan bahwa tidak terjadi perubahan pada bentuk granula pati yang telah dimodifikasi dengan menggunakan metode ikatan silang (cross-link).

Hasil modifikasi pati cross link meregangkan ikatan granula, hal ini dipengaruhi oleh jumlah natrium asetat sebagai agen cross link. Regangan ikatan ini sangatlah jelas terlihat karena pada pati sagu murni ikatan granula yeng terbentuk masih terlihat sangat kuat. Kehadiran natrium asetatsebagai agen cross-link mengakibatkan depolimerisasi dan melemahnya struktur internal granula pati, akibatnya sifat fisikokimia dari pati dapat lebih baik dibanding dengan pati sagu murni (Garrido et al., 2012).

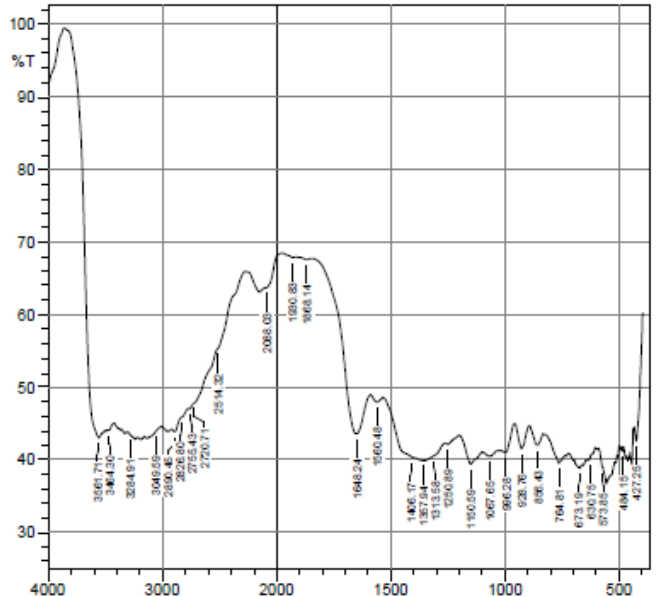

(a)

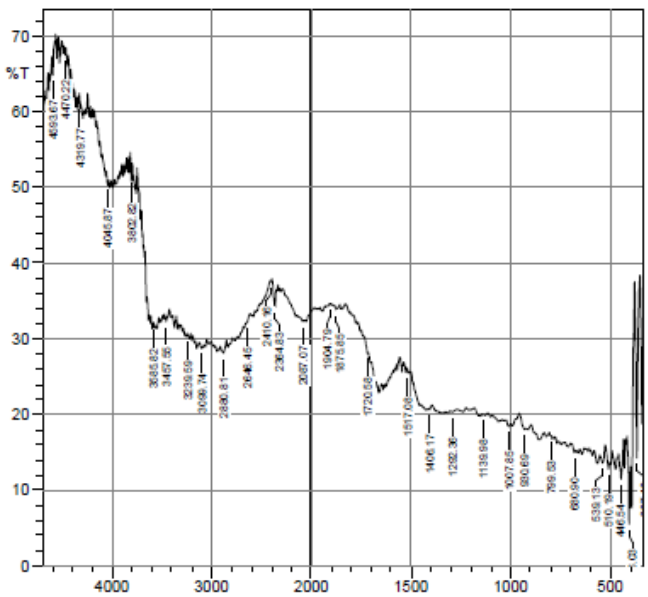

(b)

Gambar 1. Spektrum FTIR sagu alami (a), sagu modifikasi (b)

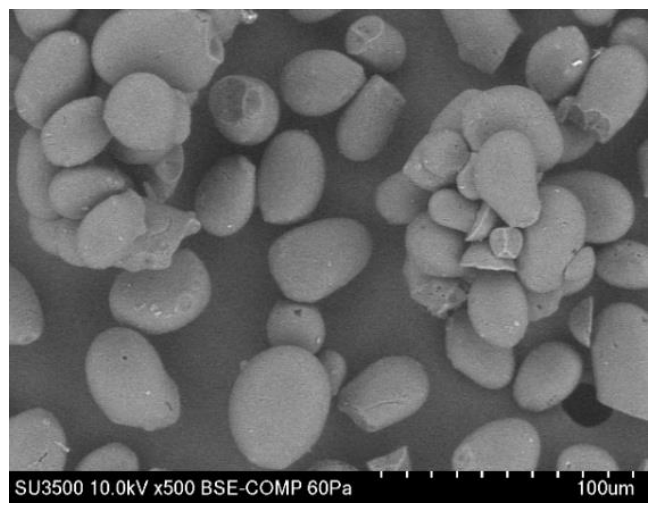

(a)

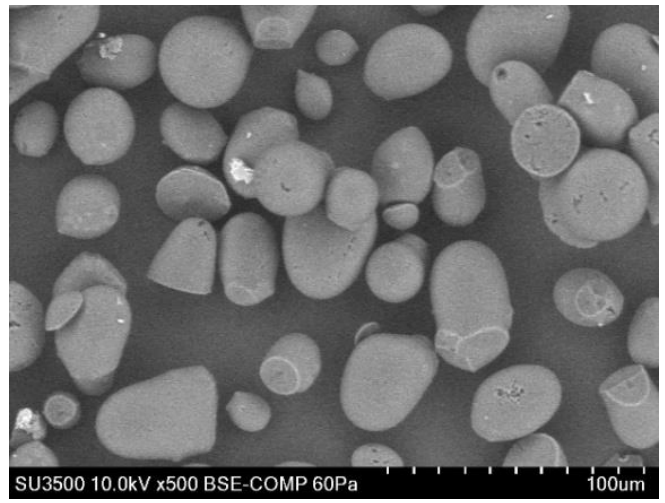

(b)

Gambar 2. Morfologi sagu alami (a), sagu modifikasi (b) 
Pengaruh cross link pati pada stabilitas termal dipelajari dengan analisis termogravimetri (TGA). TGA kurva pati sagu alami dan pati sagu modifikasi ditunjukkan pada Gambar. 3. Pati sagu alami mulai terdegradasi pada $235^{\circ} \mathrm{C}$ dengan berat residu $80 \%$, sedangkan pati sagu yang dimodifikasi cross link mulai terdegradasi pada $250^{\circ} \mathrm{C}$ dengan berat residu $90 \%$. Pati sagu murni mulai kehilangan bobot massa pada suhu $100^{\circ} \mathrm{C}$ yang disertai dengan hilangnya air. Suhu awal terjadinya dekomposisi yaitu pada suhu $235-310^{\circ} \mathrm{C}$ yang menyebabkan fragmentasi pada unit-unit pati yang berikatan silang.

Pada suhu di bawah $300^{\circ} \mathrm{C}$, pati sagu modifikasi cross link lebih rentan terhadap degradasi dibandingkan dengan pati alaminya, hal ini disebabkan karena pada pati sagu modifikasi kehadiran natrium dari agen cross link yang mudah terdegradasi. Sebaliknya, pada suhu lebih dari $300^{\circ} \mathrm{C}$ pati sagu yang di modifikasi lebih tahan terhadap degradasi termal daripada pati alami. Stabilitas termal pati modifikasi cross linkyang tinggi disebabkan oleh adanya gugus ester. Hasil TGA menunjukkan bahwa modifikasi cross link pada pati dapat mengurangi stabilitas termal hingga suhu $300^{\circ} \mathrm{C}$. Namun, stabilitas termal meningkat pada suhu lebih dari $300^{\circ} \mathrm{C}$.

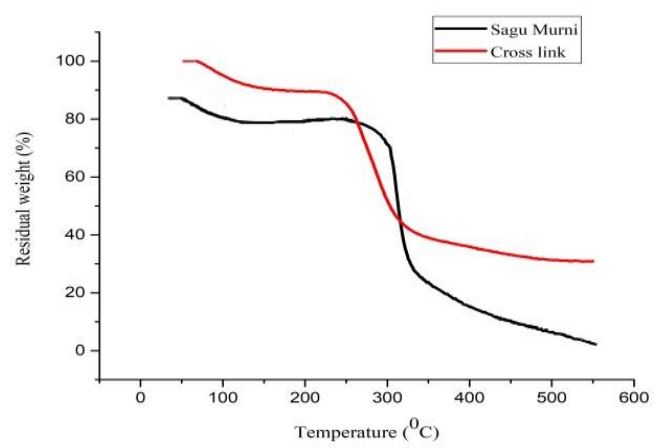

Gambar 3. Termogram dari pati sagu alami dan pati sagu modifikasi cross link

Cross-linking merupakan modifikasi pati yang berperan penting untuk meningkatkan sifat tahan panas dalam bahan edible film. Edible film yang tahan panas digunakan untuk pelapisan makanan. Oleh karena itu, penting untuk mempelajari sifat termal dari pati sebelum dijadikan edible film (Abbas et al., 2015).

\section{Karakterisasi Edible film}

Komponen penyusun edible film terdiri dari pati sagu alami dan pati sagu yang di modifikasi dan gliserol sebagai plasticizernya mempengaruhi terhadap sifat mekanik edible film yang dihasilkan. Sifat mekanik edible film yang dianalisa yaitu kuat tarik, elongasi dan ketebalannya. Karakterisasi edible film terhadap sifat mekanik dapat dilihat pada Tabel 2.

Perbedaan ketebalan antara film kemungkinan disebabkan komposisi agen cross link yang berbeda konsentrasinya pada formula film dari pati sagu yang dimodifikasi dan juga dipengaruhi oleh banyaknya total padatan dalam larutan. Edible filmakan menjadi lebih tebal bila totalpadatan dengan jumlah yang lebih banyak. Hasil pengukuran ketebalan memperlihatkan adanya kecenderungan peningkatan ketebalan film dengan semakin besarnya jumlah agen cross link yang digunakan. Hasil ketebalan edible film dengan menggunakan agen cross link $10 \%$ adalah $0,10 \mathrm{~mm}$, sedangkan pada agen cross link dengan variasi terbesar yaitu $25 \%$ menghasilkan ketebalan 0,12 mm. Semakin besar jumlah cross link yang digunakan, maka ketebalan edible film yang dihasilkan semakin besar, seperti terlihat pada Tabel 2.

Ketebalan berpengaruh terhadap penggunaan film pada produk yang akan dikemas karena akan mempengaruhi laju transmisi uap, gas, dan senyawa volatil serta sifat fisik lainnya seperti kekuatan tarik dan pemanjangan pada saat putus edible film yang dihasilkan. Menurut McHugh dan Kroctha (1993) dan Skurtys et al. (2006), ketebalan yang semakin meningkat $(<0,250 \mathrm{~mm})$ maka kemampuan penahan edible film akan semakin baik, sehingga umur simpan produk semakin panjang. Edible film yang dihasilkan pada penelitian ini memiliki ketebalan yang telah memenuhi standar dari ketebalan edible film pada umumnya.

Tabel 2. Sifat mekanik edible film dari pati sagu alami dan pati sagu modifikasi cross link

\begin{tabular}{cccc}
\hline Formula & Ketebalan $(\mathbf{m m})$ & Elongasi $\mathbf{\%})$ & Tensile strength $(\mathbf{M P a})$ \\
\hline Pati sagu murni & 0,10 & 12,32 & 9,04 \\
Sagu modifikasi cross link 10\% & 0,10 & 15,02 & 9,22 \\
Sagu modifikasi cross link 15\% & 0,11 & 14,81 & 9,76 \\
Sagu modifikasi cross link 20\% & 0,12 & 14,42 & 10,35 \\
Sagu modifikasi cross link 25\% & 0,12 & 14,07 & 12,46 \\
\hline
\end{tabular}


Pengaruh kekuatan tarik (tensile strength) terhadap ketebalan edible film dapat dilihat pada Gambar 4. Tensile strength merupakan daya renggang maksimum yang dapat diterima film sampai putus. Hasil analisis tensile strength edible film berkisar antara 9,04 sampai dengan 12,46 MPa. Dapat dilihat bahwa konsentrase agen cross link mempengaruhi kekuatan tarik dari edible film, edible film menjadi lebih transparan, homogeny dan tidak mudah patah, hal ini karena adanya ikatan silang yang dapat meningkatkan interaksi antar molekulmolekul amilosa membentuk ikatan hidrogen semakin kuatsehingga mengakibatkan matrik film akan menjadi lebih tebal, rapat, padat, dan kaku. Penelitian ini sejalan dengan Atichokudomchai et al. (2003) bahwa tensile strength edible film dipengaruhi oleh rigiditas film dan kuatnya ikatan hidrogen antar molekul-molekul amilosa sehingga struktur amilosa yang terbentuk mirip dengan siklodekstrin yang bersifat hidrofobik.

Elongasi berkaitan dengan rigiditas (kekakuan) film, apabila film tingkat rigiditas tinggi maka persen elongasi akan rendah seperti yang terlihat pada Tabel 2, sehingga dapat dikatakan persentase elongasi menunjukkan keelastisan suatu edible film. Krochta (1994) menyatakan bahwa persentase elongasi menentukan kemampuan film untuk meregang. Adanya interaksi antar molekul amilosa mengakibatkan edible film semakin rapat, padat dan kakusehingga tingkat elongasi dari edible film tidak terlalu besar. Hasil uji elongasi edible film dengan menggunakan agen cross link $10 \%$ adalah $15,02 \%$ sedangkan pada agen cross link dengan variasi $25 \%$ adalah $14,07 \%$. Semakin besar jumlah agen cross link yang digunakan, maka elongasi edible film yang dihasilkan semakin kecil, seperti terlihat pada Tabel 3 .

Kadar air edible film memberikan pengaruh terhadap penyimpanan bahan makanan karena akan memperpanjang masa simpannya dan menghambat aktifitas mikroorganisme (Diab et al., 2001). Kadar air dipengaruhi oleh sifat hidrofobisitas edible film- nya, semakin hidrofobis maka kadar air akan semakin kecil. Pada pati sagu yang dimodifikasi secara cross link, terjadinya ikatan silang antar molekul amilosa menyebabkan ikatan hidrogen antar dan inter molekul pati semakin kuat sehingga meningkatkan sifat hidrofobisitas terhadap edible film. Hal ini sejalan dengan penelitian Watanabe et al. (1966) dan Pereira et al. (2009).

Tabel 3. Kadar air dan sudut kontak edible film dari pati sagu alami dan pati sagu modifikasi cross link

\begin{tabular}{lcc}
\hline \multicolumn{1}{c}{ Formula } & $\begin{array}{c}\text { Kadar air } \\
(\%)\end{array}$ & $\begin{array}{c}\text { Sudut } \\
\text { kontak (\%) }\end{array}$ \\
\hline Pati sagu murni & 0,33 & 27,43 \\
$\begin{array}{l}\text { Sagu modifikasi cross } \\
\text { link 10\% }\end{array}$ & 0,31 & 38,92 \\
$\begin{array}{l}\text { Sagu modifikasi cross } \\
\text { link 15\% }\end{array}$ & 0,30 & 50,12 \\
$\begin{array}{l}\text { Sagu modifikasi cross } \\
\text { link 20\% }\end{array}$ & 0,28 & 53,96 \\
$\begin{array}{l}\text { Sagu modifikasi cross } \\
\text { link 25\% }\end{array}$ & 0,23 & 6775 \\
\hline
\end{tabular}

Sudutkontak (CA) merupakan parameter yang digunakan untuk memperkirakan ketahanan film terhadap air,dan menunjukkan hidrofobisitas dari permukaan film (Phan et al., 2005). Edible film dari pati sagu yang di modifikasi cross link mempunyai sudut kontak yang lebih tinggi daripada edible film pati sagu alami. Sudut kontak meningkatsecara signifikan dengan penambahan agen cross link yang mungkin disebabkan hidrof obisitas agen cross link.

Dari Gambar 4. nampak bahwa morfologi dari edible film dari pati sagu murni alami dan pati sagu yang di modifikasi dengan metoda cross link tidak jauh berbeda, yaitu menunjukkan permukaan yang halus. Edible film pati murni dan modifikasi homogen tanpa pori-pori atau retakan dan molekul pati telah terdispersi dengan baik (Garg dan Jana, 2007).

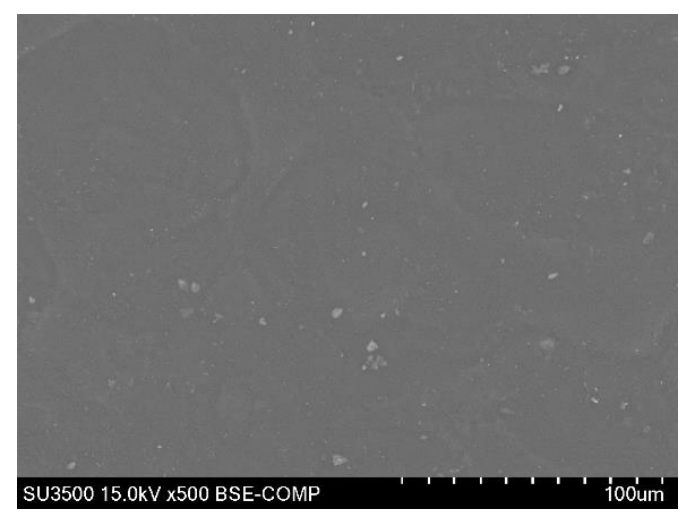

(a)

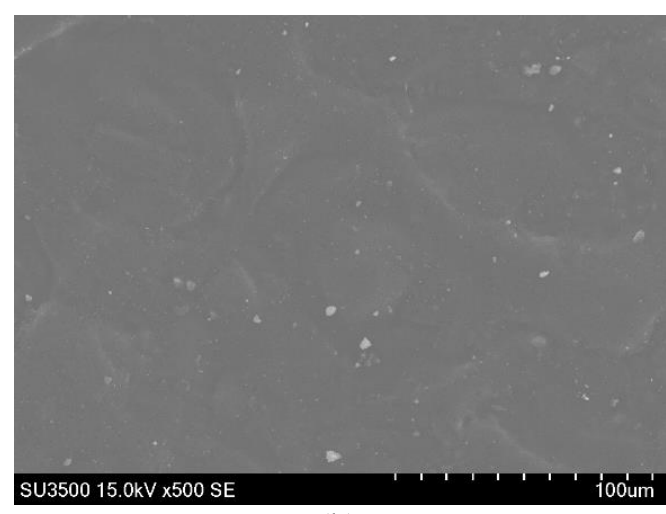

(b)

Gambar 4. Morfologi edible film pati sagu alami (a) dan pati sagu modifikasi cross link (b) 


\section{KESIMPULAN DAN SARAN}

\section{Kesimpulan}

Dari hasil penelitian ini dapat disimpulkan sebagai berikut: Munculnya peak gugus karbonil pada panjang gelombang $1720,68 \mathrm{~cm}^{-1}$ menunjukkan bahwa telah terjadi modifikasi pati sagu dengan metoda cross link.

Modifikasi pati menunjukkan perbaikan terhadap sifat kimiafisik diantaranya meningkatnya suhu gelatinisasi pada pati sagu murni $68^{\circ} \mathrm{C}$ menjadi $79^{\circ} \mathrm{C}$, meningkatnya kelarutan pati menjadi $50,1 \%$, dan menurunnya swelling power dari $15,13 \%$ menjadi 6,26\%. Pengaruh crosslink pati pada stabilitas termal menunjukkan bahwa pada suhu lebih dari $300^{\circ} \mathrm{C}$ pati sagu yang di modifikasi lebih tahan terhadap degradasi termal daripada pati alami.

Agen cross link mempengaruhi sifat mekanik dari edible film, kekuatan tarik dari edible film meningkat menjadi12,46 MPadari 9,04 MPa, dan elongasi meningkat dari $12,32 \%$ menjadi $14,07 \%$. edible film lebih transparan, homogen dan tidak mudah patah.

Sudut kontak yang tinggi dari pati sagu yang dimodifikasi $(67,75 \%)$ merupakan sifat yang diinginkan pada edible coating karena film bersifar hidrofobis, sehingga pada saat digunakan sebagai pelapis bahan pangan akan meningkatkan umur simpan dan menghambat pertumbuhan mikroba.

\section{Saran}

Perlu penelitian lanjutan mengenai modifikasi pati dengan metoda cross link untuk melihat pengaruh konsentrasi natrium asetat sebagai agent cross link, waktu dan suhu proses sehingga diperoleh kondisi optimum yang akan mempengaruhi terhadap karakteristik pati sagu dan edible coating yang dihasilkan.

\section{UCAPAN TERIMAKASIH}

Penulis mengucapkan terimakasih kepada kementrian Riset dan Teknologi DIKTI yang telah memberikan dana penelitian melalui INSINAS 2018.

\section{DAFTAR PUSTAKA}

Abdorreza MN, Robal M, Cheng LH, Tajul AY, Karim AA. 2012. Physicochemical, thermal, and rheological properties of acid-hydrolyzed sago (Metroxylon sagu) starch. Journal Food Science and Technology. 46: 135-141.

Abbas A, Hussain M, Amin M, Paracha R, Ameer M dan Hussain M. 2015. Green synthesis, thermal analysis and degradation kinetics of cross-linked potato starch. Journal Chemical Society Pakistan. 37(2):277-283.

Acquarone VM dan Rao MA. 2003. Influence of sucrose on the rheology and granule size of cross-linked waxy maize starch dispersions heated at two temperatures. Carbohydrate Polymers. 51:451-458.

Akpa, Gunorubon J, Dagde, Kekpugile K. 2012. Modification of cassava starch for industrial use.) International Journal Engineering \& Technology. 2: 913-919.

Alejandro A, Felipe G, Francisco J, Juscelino T, Luis AB. 2008. Physicochemical and functional properties of cross-linked banana resistant starch. effect of pressure cooking. Starch. 60 (6): 286-291.

Atichokudomchai N dan Varavinit S. 2003. Characterization andutilization of acid modified cross linked tapioca starch in pharmaceutical tablets. Carbohydrate Polymers. 53: 263-270.

Austin GT. 1984. Shreve's Chemical Process Industries. Fifth Edition, McGraw-Hill Book Company.

Chel-Guerrero L, Betancur AD. 1998. Cross-linkage of canavalia ensiformus starch with adipic acid: chemical; and functional properties. Journal Agricultur and Food Chemical. 46 (6): 2087-2091.

Chopin N, Guillory X, Weiss P, Le Bideau, ColliecJouault TS. 2014. Design polysaccharides of marine origin: chemical modifications to reach advanced versatile compounds. Current Organic Chemistry.18(7): 867-895.

Choi SG dan Kerr WL. 2004. Swelling characteristics of native and chemically modified wheat starches as a function of heating temperature and time. Starch. 56: 181-189.

Davies EM, Labuschagne MT, Koen E, Benesi IRM, Saka JDK. 2008. Some properties of starches from cocoyam (Colocasia esculenta) and cassava (Manihot esculenta Crantz) grown in Malawi. African Journal Food Science. (2): 102-111.

Diab $\mathrm{T}$ dan Biliaderis GCG, Gerasopoulos D, Sfakiotakis E. 2001. Physicochemical properties and application of pullulan edible films and coatings in fruit preservation. Journal Food Science. 81: 988-1000.

Fellow PJ. 2000. Food Processing Technology, Principle and Practice. CRC Press. Cambridge, England.

Garg S dan Jana AK. Studies on the properties and characteristics of starch-LDPE blend films using cross-linked, glycerol modified, crosslinked and glycerol modified starch. European Polymer Journal. 43: 3976-3987.

Garrido LH, Schnitzler E, Zortea MEB, Rocha TS, Demiate IM. 2012. Physischochemical properties of cassava starch oxidized by sodium hypochlorite. Journal Food Science Technololy. 51(10): 2640-2647. 
Herlina. 2010. Karakterisasi sifat fisik, kimia dan fungsional bahan pati umbi gembili (Dioscorea esculenta L.) termodifikasi secara ikatan silang dengan natrium tripolifosfat. AGROTEK. 4(1): 60-67.

Hoover R dan Sosulski F. 1986. Effect of crosslinking on Functional properties of legume starches. Starch. 38(5): 149-155.

Huang J, Schols HA, Jin Z, Sulmann EY, Voragen AGJ. 2007. Characterization of differently sized granule fractions of yellow pea, cowpea and chickpea starches after modification with acetic anhydride and vinyl acetate. Carbohydrate Polymers. 67: 11-20.

Krochta JM, Baldwin EA, Nisperos-Carriedo MO. 1994. Edible Coatings and Films To Improve Food Quality. USA : Technomic Publication. Co. Inc.

Kuakpetoon D dan Wang YJ. 2006. Structural characteristics and physicochemical properties of oxidized corn starches varying in amylase content. Carbohydr Res. 341: 1896-1915.

Mahmut S dan Sosulski, F. 2004. Cross-linking starch at various moisture contents by phosphate substitution in an extruder. Science Direct. 59(4): 541-544.

McHugh T dan Rand Krochta JM. 1993. Dispersed phase particle size effects on water vapor Permeability of whey protein-beeswax edible emulsion films. J Food Process Press. 18: 173-188.

Mirmoghtadaie L, Mahdi Kadivar M, Shahedi M. 2009. Effects of cross-linking and acetylation on oat starch properties. Food Chem. 116:709-713.

Miyazaki MR, Hung PV, Maeda T, Morita N. 2006. Recent advances in application of modified starches for bread making. Trends in Food Sci Technol. 17: 591-599.

Moreno O, Cardenas J, Atarés L, Chiralt A. 2017. Influence of starch oxidation on the functionality of starch-gelatin based active films. Carbohydrate Polymers. 178:147-158.

Pereira L, Amado AM, Critchley AT, van de Velde F, Ribeiro-Claro PJA. 2009. Identification of selected seaweed polysaccharides (phycocolloids) byvibrational spectroscopy (FTIR-ATR and FT-Raman). Food Hydrocoll. 23 (7): 1903-1909.

Phan TD, Debeaufort F, Luu D, Voilley A. 2005. Functional properties of edible agar based and starch-based films for food quality preservation. Journal Agric. Food Chem. 53:973-981.

Rivera SMM, Garcia-Suarez FJL, Velazquez VM, Gutierrez-Meraz F, Bello-Perez LA. 2005. Partial Characterization of banana starchesoxidized by different levels of sodium hypochlorite. Carbohydrate Polymers. 62:5056.

Sasaki T dan Masuki J. 1998. Effect of wheat structure on swelling power. Cereal Chemistry. 75: 525-529.

Singh S, Gamlath S, Wakeling L. 2007. Nutritional aspects of food extrusion: A review. Journal Food Science and Technology 42(8): 916929.

Skurtys O, Acevedo C, Pedreschi F, Enrions J, Osorio F, Aquilera JM. 2011. Food hydrocolloid edible films and coating. Department of Food Science and Technology. Chile: Universidad de Santiago de Chile.

Sodhi NS dan Singh N. 2005. Characteristics of acetylated starches prepared using starches separated from different rice cultivars. Journal Food Engineering . 70: 117-127.

Srichowang S, Sunarti TC, Mishima T, Isono N, Hisamatsu M. 2005. Starches from different botanical sources II: Contribution of starch structure to swelling and pasting properties. Carbohydrate Polymers. 62: 25-34.

Teja AW, Sindi I, Ayucira A, Setiawan EKL. 2008. Karakteristik pati sagu dengan metode modifikasi asetilasi dan cross-linking. Jurnal Teknik Kimia Indonesia 7 (3):836-843.

Wang YJ dan Wang, L. 2003.Physicochemical properties of common and waxy corn starches oxidized by different levels of sodium hypochlorite. Carbohydr Polym. 52:207-217.

Watanabe T, Ohtsuka A, Murase N, Barth P, Gersonde K. 1996. NMR studies on water and polymer diffusion in dextran gels. Influence of potassium ions on microstructure formation and gelation mechanism. Magnetic Resonance Medicine Journal . 35 (5): 697-705.

Winarno FG. 1989. Kimia Pangan dan Gizi. Jakarta: PT. Gramedia.

Wurzburg OB. 1989. Modified Starch : Properties and Uses. Boca Raton: CRC Press.

Yuliasih I. 2008. Fraksinasi dan asetilasi pati sagu (metroxylon sagu rottb) serta aplikasi produknya sebagai bahan campuran plastik sintetik. [Disertasi]. Program Pascasarjana. Program Studi Ilmu Pangan.Institut Pertanian Bogor, Bogor. 